\title{
Article
}

\section{Serum Aspartate Aminotransferase (AST) and Alanine Aminotransferase (ALT) Levels in Different Grades of Protein Energy Malnutrition}

\author{
Chowdhury MSI', Rahman ABMZ², Haque $\mathbf{M}^{3}$, Nahar $\mathbf{N}^{4}$, Taher $\mathbf{A}^{5}$
}

The present study was designed to analyze serum AST, ALT levels in different grades of protein energy malnutrition to facilitate early diagnosis, management and rehabilitation of PEM.

The serum AST and ALT levels of 50 children of aged 5months to 5 years of both sexes were studied. Among them, 30 children suffering from protein energy malnutrition of 3 different grades were selected for experimental group. Age and sex matched 20 apparently healthy children with no systemic disorder and with weight/height ratio greater than $80 \%$ were included in control group. Serum AST and ALT levels were measured by kinetic ultraviolet method according to International Federation of Clinical Chemistry.. Data were analyzed statistically by un paired student " $t$ ” test.

Mean Serum AST and ALT levels of different grades of protein energy malnutrition were significantly higher $(\mathrm{p}<0.001)$ than that of control. Values of mean serum AST and ALT levels were highest in grade-I PEM and it were significantly higher $(\mathrm{p}<0.001)$ than both grade-II and grade-III. Again mean serum AST and ALT levels were significantly higher $(\mathrm{p}<0.001)$ in grade-II PEM than that of grade-III PEM. The elevated levels of serum AST and ALT is due to tissue break down and hepatobiliary disorder. The results of this study indicate that serum ALT and AST levels are increased in PEM which varies according to its severity.

Key Words: Aminotranserase; Malnutrition; Protein

\section{Introduction}

$\mathbf{M}$

alnutrition is one of the common public health problem and a leading cause of mortality in Bangladesh. Children under 06 years are victims of different grades of malnutrition ${ }^{1}$. Both ALT and AST are nonfunctional plasma enzymes and they are present in blood at level million fold lower than in tissues. Their presence in plasma at levels above normal suggests increase rate of tissue destruction ${ }^{2}$.

The assay of these enzyme activities in PEM is very useful to detect tissue damage that may occur in PEM before clinical manifestations are

J Bangladesh Soc Physiol. 2007 Dec;(2): 17-19. established ${ }^{4}$ and thus help in reducing problem created by PEM.

\section{Methods}

The study was carried out in 50 (fifty) children of 06 (six) months to 05 (five) years of age of both sexes. Thirty (30) children suffering from various grades of PEM were selected as experimental group and excludes hepatobiliary and other disease by history and physical examination. Age and sex matched twenty (20) apparently healthy children with no systemic disorder and in terms of median Harvard standard 


\section{Article}

Weight/Height ratio more than $80 \%$ were taken as control group. The attendant parents of the patients was put through a questioners to collect data related to the study and verbal consent were taken from them for participation of his/her child in the study. Patients for experimental group were collected from BSMMU, child nutrition unit of Dhaka Shisu Hospital and Dhaka Medical College Hospital.

PEM cases were classified in to Grade -I, II and III according to classification set by Gomez, shown in Table - I.

Table - I : Gomez classification of PEM

\begin{tabular}{lc}
\hline Degree of PEM & $\begin{array}{c}\text { Percent of desired body } \\
\text { weight for age and sex }\end{array}$ \\
\hline Normal & $90 \%-100 \%$ \\
Grade -I. Mild & $75 \%-89 \%$ \\
Malnutrition & \\
$\begin{array}{l}\text { Grade - II. Moderate } \\
\text { Malnutrition }\end{array}$ & $60 \%-74 \%$ \\
$\begin{array}{l}\text { Grade -III, Severe } \\
\text { Malnutrition }\end{array}$ & $<60 \%$ \\
\hline
\end{tabular}

Aminotransferase in Protein Energy Malnutrition

Blood sample was drawn with all aseptic precaution and serum AST was determined by kinetic ultraviolet method according to the recommendation of international federation of clinical chemistry (IFCC) ${ }^{5}$. Serum ALT also determined by international federation clinical chemistry (IFCC) ${ }^{6}$. Statistical analysis of the result was done by unpaired student "t"-test.

\section{Results}

Mean serum AST and ALT levels in grade - I, grade - II and grade - III PEM were significantly higher $(p<0.001)$ than that of control (Table - II). Serum AST and ALT levels in grade -I, PEM are significantly higher $(\mathrm{p}<0.001)$ than that of grade - II and grade III, PEM. When comparison was done between grade -II PEM and grade-III PEM, it was found that serum AST and ALT levels in gradeII PEM was significantly higher that of grade -III PEM.

Table - II : Shows mean $( \pm$ SE) serum AST and ALT levels in control and different grades of PEM.(n=50)

\begin{tabular}{lcccc}
\hline Parameters & Control & Grade -I PEM & Grade -II PEM & Grade -III PEM \\
& $\mathrm{n}=20$ & $\mathrm{n}=10$ & $\mathrm{n}=10$ & $\mathrm{n}=10$ \\
\hline AST U/L & $32.30 \pm 0.50$ & $96.62 \pm 2.18^{* * *}$ & $73.58 \pm 0.96^{* * *}$ & $64.88 \pm 1.33^{* * *}$ \\
ALT U/L & $29.88 \pm 0.14$ & $100.78 \pm 1.26^{* * *}$ & $86.41 \pm 1.7^{* * *}$ & $69.04 \pm 1.54^{* * *}$ \\
\hline
\end{tabular}

*** $\mathrm{P}<0.001=$ Highly Significant

\section{Discussion}

In this study, serum AST and ALT levels in grade -1 , grade-II, and grade -III PEM were significantly higher than that of control. Similar findings are also reported by other workers $3,4,7$. It has been suggested that elevated value of serum AST and ALT are due to tissue breakdown and hepatobilliary disorder. In order to metabolize the amino acids released from exaggerated tissue breakdown, the process of transmutation is enhanced leading to increase activity of related enzymes AST and ALT ${ }^{3,4,7}$.In absence of clinical liver disorder, the increase in serum AST and ALT are possibly due to tissue breakdown.

The increase in mean serum AST and ALT level is maximum in grade-I PEM. In grade-II, increase serum AST and ALT is significantly higher than grade-III PEM.

In all grades of PEM, serum AST and ALT are significantly higher than that of control. This may reflect the effort on the part of the body to 
maintain homeostasis through protein synthesis, mobilizing amino acid from tissue breakdown. Any grade of PEM can be associated with alteration in the level of serum enzymes. Many of the abnormalities result from metabolic readjustment due to protein deficiency ${ }^{3}$. The out come of this study may help the physician for early diagnosis of PEM on biochemical basis and could help to detect its severity .

\section{Conclusion}

It may concluded that serum AST and ALT were increased in protein energy malnutrition and this varied according to its severity.

\section{Author Affiliations}

* 1. Md Serajul Islam Chowdhury, Assistant Professor of Biochemistry, Chittagong Medical College, Chittagong

2. ABM Ziaur Rahman, Assistant Professor of Biochemistry, Dhaka Medical College, Dhaka

3. Mahmudul Haque, Professor of Biochemistry, Chittagong Medical College, Chittagong

4. Nazibun Nahar, Lecturer of Physiology, Chittagong Medical College, Chittagong

5. Abu Taher, Assistant Professor of Physiology, Chittagong Medical College, Chittagong

* For correspondence

\section{References}

1. Bangladesh bureaus of statistics. Report of the child nutrition status survey, 1995-96. Dhaka. Bangladesh Bureau of Statistics. 1996-:22-39.

2. Kumer V, Chandra sekharan R, Belavalgibed M.I, Blood biochemical tests in the diagnosis of malnutrition, Indian Pediatrics. 1975,12(10):955-60.

3. Kumari R Raoy N, Talukder B,Agarwal S, Puri RK serum enzyme abnormalities in protein energy malnutrition, Indian Pediatrics. 1993:30(4):469-73.

4. Osifo BOA \& Bloodekujo. Serum aspartate and alanine aminotransferase activities in protein energy malnutrition. Enzymes. 1982;28:300-4.

5. Caddel JL. Studies in protein calorie malnutrition. New Eng J Med. 1976;276 (10):515-39.

6. Coward BWA, Whitehead RG \& Coward DG. Quantitative changes in serum protein fractions during the development of kwashiorkor and in recovery. Br J Nutr. 1972;28: 433-4.

7. Grova AK,Singh H. Mehta HC, Saini AS, Dhattps, Socd SC. Biochemical assessment of PEM. Indian Pediatrics. 1985; 22: 35-40. 